\title{
Global Financial Crisis of 2008, Asymmetric Effects of Exchange Rate Changes, and Stability of the Demand for Money in Japan
}

\author{
Mohsen Bahmani-Oskooee ${ }^{1, *}$ and Jungho Baek ${ }^{2}$
}

\author{
${ }^{1}$ The Center for Research on International Economics, The Department of Economics, University of \\ Wisconsin-Milwaukee, Milwaukee, WI 53201, USA \\ ${ }^{2}$ Department of Economics, School of Management, University of Alaska Fairbanks, USA
}

\begin{abstract}
We wonder if Global Financial Crisis of 2008 affected stability of the demand for money in Japan. In testing this hypothesis we deviate from previous studies which either excluded the exchange rate from money demand function in Japan or have not been able to find any significant relation between the exchange rate and the demand for money. While we address stability of the demand for money, we show that failure to find a cointegrating relation or significant effects could be due to assuming a linear model in which exchange rate changes have symmetric effects. Once we consider a nonlinear ARDL approach of Shin et al.'s (2014), we show that not only variables in the money demand are cointegrated but exchange rate changes have asymmetric effects. In the long run, while appreciation of yen has significantly positive effect on the demand for money in Japan, depreciation does not. We also find a stable money demand which was not affected by 2008 financial crisis.
\end{abstract}

Keywords: Nonlinear ARDL Approach, Symmetry versus Asymmetry, Money Demand, Japan.

\section{INTRODUCTION}

Monetary policy is said to be effective if it results in changes in prices and output in theoretically expected direction. Such effectiveness requires that the velocity of money to be stable. Since velocity represents the linear combination of all the variables in the money demand function, establishing stability of velocity amounts to testing for stability of the demand for money. In testing for stability of the demand for money, whenever researchers have come short, they have tried to include some missing variables in their specification. For example, McNown and Wallace (1992) who investigated the stability of M1 and M2 demand for money in the U.S. concluded that "long-run stationarity of the demand function for M2 (but not M1) requires inclusion of the effective exchange rate". Of course, we must recognize that Mundell (1963, p. 484) was the first who argued that the demand for money could depend upon the exchange rate in addition to interest rate and income, though without any empirical support. Many other studies have followed this path and included the exchange rate in their specification of money demand function. The list includes Arango and Nadiri (1981) for Canada, Germany, UK., the US., Domowitz and Elbadawi (1987) for Sudan, Marquez (1987) for Venezuela, Bahmani-Oskooee and Malixi (1991) for 13 developing countries, Karfakis (1991) for

\footnotetext{
*Address correspondence to this author at The Center for Research on International Economics, The Department of Economics, University of Wisconsin-Milwaukee, Milwaukee, WI 53201, USA; Tel: 414-229-4812

Fax: 414-229-3860; E-mail: bahmani@uwm.edu

JEL Classification: F31, F40.
}

E-ISSN: 1929-7092/16
Greece, Bahmani-Oskooee (1996) for Iran, Civcir (2003) for Turkey, Harb (2004) for six oil producing countries, and Bahmani-Oskooee et al. (2012) for China.

The literature on the demand for money is so vast that each country has its own literature. Since this paper is about money demand in Japan, a brief review is in order so that we can highlight contribution of this paper. We classify Japan-related studies into two groups. The first group includes studies that did not include the exchange rate in their specification and the second group includes those that did include the exchange rate. Fair (1987) estimated a money demand function in which only income and interest rate were included as determinants. Japan was one of 27 countries in the sample. While income carried an insignificant coefficient, interest rate carried a significantly negative but very small $(-0.005)$ coefficient. Since Fair (1987) did not test for integrating properties of variables nor did he test for cointegration among the variables, his findings could be considered spurious. ${ }^{1}$ To remedy the situation, Hoffman et al. (1995) employ Johansen's cointegration approach and estimate the M1 demand for money in five industrial countries that included Japan. After imposing a unitary income elasticity, they estimate the interest rate elasticity to be about -0.5 . They not only establish cointegration among variables, but also show that estimates are

\footnotetext{
${ }^{1}$ There was no indication whether Fair (1987) used M1 or M2 definition of the money supply.
}

๑) 2016 Lifescience Global 
stable. Note that Hoffman et al. (1995) estimated the money demand recursively by shifting observations. If their trace statistic was adjusted by the factor proposed by Cheung et al. (1993), cointegration would have disappeared in several cases for Japan. As for M2 demand for money in Japan, Miyao (1996) used three alternative cointegration methods to show that real M2 monetary aggregate in Japan is not cointegrated with real output and nominal interest rate. Similar results (lack of cointegration) between real M2, real income, and interest rate was also found by Bahmani-Oskooee (2001) who used Pesaran et al.'s (2001) Autoregressive Distributed Lag (ARDL) approach.

Can we support cointegration between real M2, income and interest rate in Japan if we include the exchange rate in our specification, an approach similar to that of McNown and Wallace (1992) for the U.S.? That is exactly what Bahmani-Oskooee and Shabsigh (1996) did by using Johansen's cointegration method. Without including nominal effective exchange rate in their specification, they find no cointegration among real $\mathrm{M} 2$, real income and interest rate in Japan. However, when nominal effective exchange rate is added, cointegration is supported. They then reported an income elasticity of 1.02 , an interest rate elasticity of -0.42 and an exchange rate elasticity of 0.33 . However, since they failed to report results from Johansen's exclusion test, it is not clear which determinant of the demand for money was significant or which variables were responsible for cointegration. After all, cointegration could be due to strong relation between some of the variables and not all of the variables. ${ }^{2}$

Some of the above studies that included the exchange rate in their specifications have assumed that the effects of exchange rate changes are symmetric, i.e., if currency depreciation results in an increase in demand for domestic currency, appreciation should result in a decrease and by the same proportion. How valid is this assumption? Could exchange rate changes have asymmetric effects due to different response by public to exchange rate changes? It is the main purpose of this paper to answer these questions by considering the demand for real M2 in Japan one more time. Since answering symmetry effects versus asymmetry effects will require using

${ }^{2}$ Note that similar results for Japan was also reported by Bahmani-Oskooee and Chomsisengphet (2002) who, again, applied Johansen's technique to M2 money demand in 11 industrial countries including Japan. nonlinear dynamic adjustment process, this study could be considered the first to apply such nonlinear method to demand for money in Japan. To that end, in Section II we introduce the models and estimation method. We report the results in Section III and summarize the paper in Section IV. Finally, we cite the source of the data and definition of the variables in an Appendix.

\section{THE MODELS AND METHODS}

As mentioned above Bahmani-Oskooee and Shabsigh (1996) estimated the demand for real M2 in Japan by including real income $(Y)$, nominal interest rate $(r)$, and nominal effective exchange rate $(E X)$ as long-run determinants. Therefore, here we adopt their specification outlined by equation (1):

$$
L n M_{t}=a+b \operatorname{Ln} Y_{t}+c \operatorname{Ln} r_{t}+d \operatorname{LnEX} X_{t}+\varepsilon_{t}
$$

where $M$ is a measure of real M2. Real income $(Y)$ is included to account for transaction demand for money and interest rate $(r)$ is included to account for opportunity cost of holding money. We expect an estimate of $b$ to be positive and that of $c$ to be negative. Finally, the nominal effective exchange rate $(E X)$ is included to account for currency substitution. By way of construction, a decline in EX signifies depreciation of Japanese yen or appreciation of foreign currencies. As foreign currencies appreciate or yen depreciates, domestic currency value of foreign assets rise and if this is perceived as an increase in wealth by Japanese, their consumption and thus, their demand for domestic money will increase, resulting in a negative estimate for $d$. On the other hand, as foreign currencies appreciate, if there are expectation of further appreciation, Japanese may hold more of foreign currency and less of domestic currency, hence a positive estimate for $d$.

Equation (1) is said to be a long-run model. In order for the estimates to be stable, almost all studies try to incorporate short-run dynamics by turning (1) into an error-correction specification. While estimate of equation (1) yields long-run estimates, estimate of an error-correction model yields short-run estimates. Therefore, one has to take two steps in applying cointegration and error-correction methods of Engle and Granger (1987) and Johansen (1988). However, in turning (1) into an error-correction model we follow Pesaran et al.'s (2001) bounds testing approach where estimating their specification yields both short-run and long-run coefficient estimates. As such, the following error-correction model is adopted: 


$$
\begin{aligned}
\Delta L n M_{t}= & \alpha+\sum_{i=1}^{n 1} \beta_{i} \Delta \operatorname{LnM}_{t-i}+\sum_{i=0}^{n 2} \delta_{i} \Delta \operatorname{Ln} Y_{t-i}+\sum_{i=0}^{n 3} \phi_{i} \Delta L n r_{t-i} \\
& +\sum_{i=0}^{n 4} \eta_{i} \Delta \operatorname{LnEX_{t-i}}+\rho_{0} \operatorname{Ln} M_{t-1}+\rho_{1} \operatorname{Ln} Y_{t-1}+\rho_{2} L n r_{t-1} \\
& +\rho_{3} \operatorname{LnEX_{t-1}}+\varepsilon_{t}
\end{aligned}
$$

Once (2) is estimated, short-run estimates are those coefficients that are attached to first-differenced variables. The long-run effects are obtained by estimates of $\rho_{1}-\rho_{3}$ normalized on $\rho_{0}{ }^{3}$ However, for the long-run estimates not to be spurious, Pesaran et al. (2001) recommend applying the familiar $F$ test to establish joint significance of lagged level variables as a sign of cointegration. They tabulate new critical values for the $F$ test which accounts for integrating properties of variables. They also demonstrate that their upper bound critical value could be used when we have combination of $I(0)$ and $I(1)$ variables. ${ }^{4}$ This is another advantage of this approach over EngleGranger and Johansen's methods which require all variables in a given model to be $I(1) .^{5}$

Models such as (2) assume that the effects of exogenous variables such as the exchange rate are symmetric. We test symmetry versus asymmetry effects of exchange rate changes by basically constructing two time series variables, where one represents depreciation and the other one represents appreciation. To that end, we first generate exchange rate changes by $\triangle L n E X_{t}$. Next, we use the concept of partial sum and construct our two measures as:

$$
\begin{aligned}
& \operatorname{LnEX}_{t}^{+}=\sum_{j=1}^{t} \Delta \operatorname{LnEX_{j}^{+}}=\sum_{j=1}^{t} \max \left(\Delta \operatorname{LnEX} X_{j}, 0\right),
\end{aligned}
$$

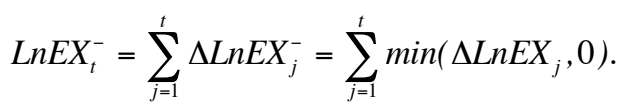

where $L n E X_{t}^{+}$and $L n E X_{t}$ are the partial sum process of positive and negative changes in $L n E X$. Shin et al. (2014) then propose replacing $L n E X_{t}$ variable in equation (2) by our two newly constructed variables as follows:

\footnotetext{
${ }^{3}$ For details of normalization procedure see Bahmani-Oskooee and Tanku (2008).

${ }^{4}$ Indeed, we had to make sure that there is no I(2) variable.

${ }^{5}$ For applications in other areas see Halicioglu, F., (2007), Narayan et al. (2007), Tang (2007), Mohammadi et al. (2008), Wong and Tang (2008), De Vita and Kyaw (2008), Payne (2008), Chen and Chen (2012), and Hajillee and AlNasser (2014).
}

$$
\begin{aligned}
\Delta L n M_{t}= & a+\sum_{i=1}^{n 1} b_{i} \Delta \operatorname{LnM_{t-i}}+\sum_{i=0}^{n 2} c_{i} \Delta \operatorname{Ln} Y_{t-i}+\sum_{i=0}^{n 3} d_{i} \Delta L n r_{t-i} \\
& +\sum_{i=0}^{n 4} e_{i} \Delta \operatorname{LnEX_{t-i}^{+}}+\sum_{i=0}^{n 5} f_{i} \Delta L n E X_{t-i}^{-} \\
& +\theta_{0} L n M_{t-1}+\theta_{1} L n Y_{t-1}+\theta_{2} L n r_{t-1}+\theta_{3} L n E X_{t-1}^{+} \\
& +\theta_{4} \operatorname{LnEX}_{t-1}^{-}+\xi_{t}
\end{aligned}
$$

They then demonstrate that all tests and interpretation that were discussed above with regards to estimating equation (2) are equally applicable to specification (5). Whereas model (2) is labeled linear ARDL model, they label model (5) a nonlinear ARDL model due to method of constructing the two new variables. Once (5) is estimated, short-run asymmetry is judged by comparing estimates of $e_{i}$ to those of $f_{i}$. Long-run asymmetry is inferred by comparing normalized estimate of $\theta_{3}$ to $\theta_{4}$. If estimates carry the same sign and size, the effects are said to be symmetric. Otherwise, they are asymmetric. ${ }^{6}$

\section{THE RESULTS}

In this section, we estimate the linear ARDL model outlined by equations (2) first and the nonlinear ARDL model outlined by (5) next using quarterly data over the period 1973:Q1-2014:Q3 for Japan. Akaike's Information Criterion (AIC) is used to select the optimum models after imposing a maximum of four lags on each first-differenced variable. In order to account for Global Financial Crisis of 2008, we include a dummy variable which takes a value of zero prior to 2008 and one thereafter. The results from each optimum model are reported in Tables 1 for the linear model and Table 2 for the nonlinear model. Note that there are three panels in each table. While Panel A reports the short-run coefficient estimates, Panel $B$ reports the long-run estimates. Diagnostic statistics for each model are reported in Panel C.

Let us consider Table 1 and the results from linear model first. From the short-run results in Panel $A$, we gather that both income and interest rate carry at least one significant coefficient, indicating that both variables have short-run effects on the demand for money in Japan. However, from Panel B, it is clear that only the effects of income lasts into the long run, since it carries a highly significant and positive coefficient. The exchange rate is insignificant in the short run as well as

\footnotetext{
${ }^{6}$ For some other applications of this approach, see Apergis and Miller (2006), Delatte and Lopez-Villavicencio (2012), Verheyen (2013), and BahmaniOskooee and Bahmani (2015)
} 
Table 1: Full Information Estimate of Linear ARDL Equation (2)

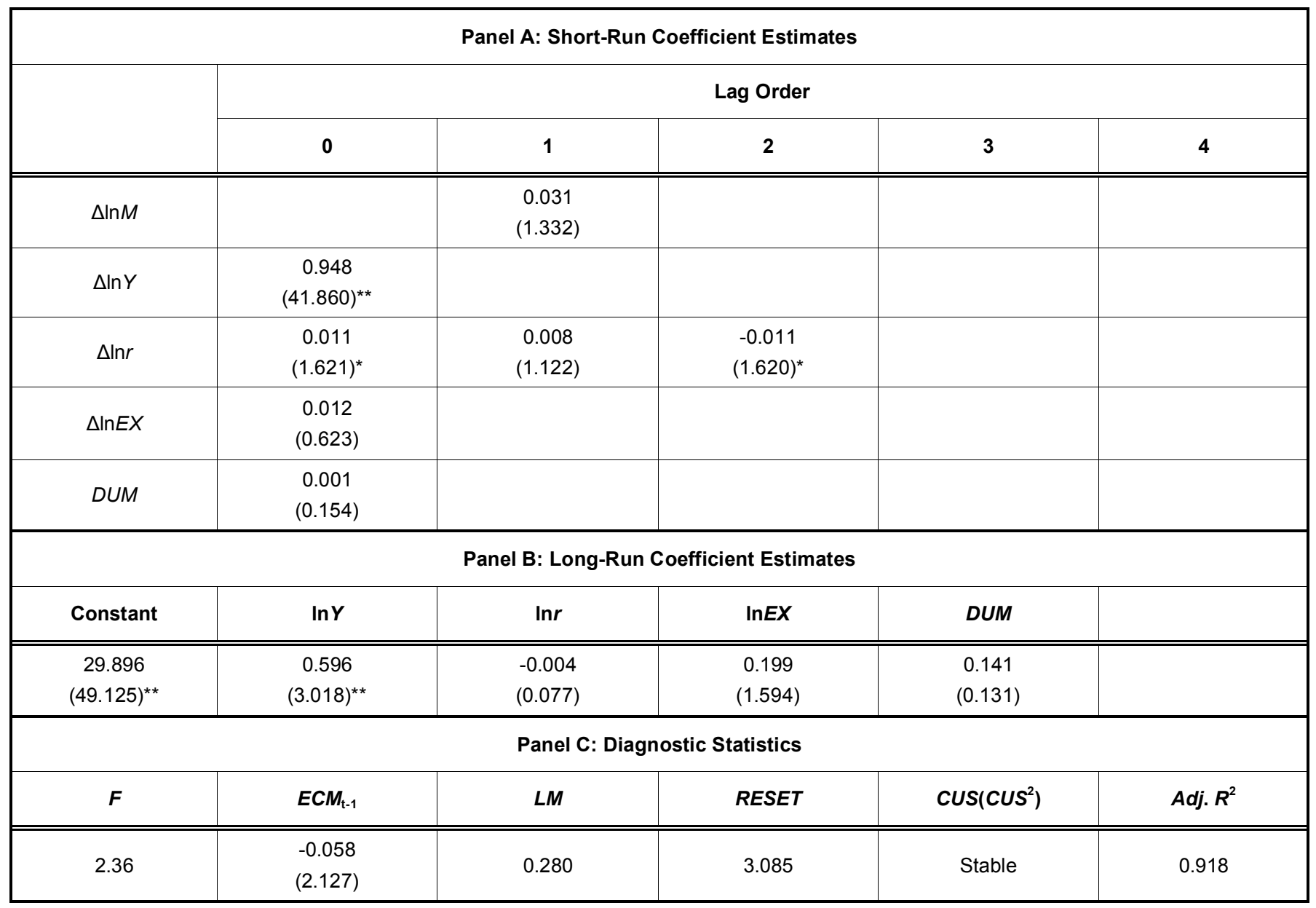

Notes:

a. Numbers inside the parentheses are absolute values of the $t$-ratios.

b. The upper critical bound value of the F-statistic at the $10 \%$ significance level is 3.77. This comes from Pesaran et al. (2001), Table Cl-Case III.

c. The critical value of the t-test for significance of $\mathrm{ECM}_{\mathrm{t}-1}$ is -3.47 at the $10 \%$ significance level. This comes from Banerjee et al. (1998, Table 1).

d. LM and RESET are the Lagrange multiplier test of serial correlation and Ramsey's test or functional form, respectively. These tests are based a $X^{2}$ distribution with one degree of freedom. The critical value at the $5 \%$ significance level is 3.84 .

e. ${ }^{* *}$ and ${ }^{*}$ denote significance at the $5 \%$ and $10 \%$ levels, respectively.

in the long run and so is the dummy, implying that Global Financial Crisis of 2008 had neither short-run nor long-run effects on the demand for money in Japan.

Is the long run link between quantity of money demanded and income in Japan meaningful? To answer this question, we turn to Panel $\mathrm{C}$ and the results of the $F$ test for cointegration. Clearly, our calculated $F$ statistic is much less than its critical value of 3.77 at the $10 \%$ significance level, rejecting the existence of cointegration. ${ }^{7}$ Is cointegration supported if we use an alternative test? Following Pesaran et al. (2001) and Bahmani-Oskooee and Tanku (2008), we

${ }^{7}$ The critical value comes from Pesaran et al. (Table Cl(iii) Case III, p. 300), where number of exogenous variables is three. use long-run normalized coefficient estimates and longrun model (1) to generate the error term, labeled ECM. After replacing the linear combination of lagged level variables in (2) by $E C M_{\mathrm{t}-1}$ and after imposing the same optimum lags from Panel $A$, we estimate this new specification one more time. A significantly negative coefficient obtained for $E C M_{\mathrm{t}-1}$ will not only support convergence toward long-run, but also cointegration. However, as demonstrated by Banerjee et al. (1998), the $t$-ratio that is used to judge the significance of this coefficient has new critical values that they tabulate. Given the critical value of -3.47 at the $10 \%$ significance level, clearly the estimated coefficient of -0.07 is insignificant, again rejecting cointegration. ${ }^{8}$

\footnotetext{
${ }^{8}$ Note that this critical value of -3.47 is for 100 observations and three
} 
Table 2: Full Information Estimate of Nonlinear ARDL Equation (5)

\begin{tabular}{|c|c|c|c|c|c|}
\hline \multicolumn{6}{|c|}{ Panel A: Short-Run Coefficient Estimates } \\
\hline & \multicolumn{5}{|c|}{ Lag Order } \\
\hline$\Delta \ln Y$ & $\begin{array}{c}0.88 \\
(27.071)^{\star \star}\end{array}$ & $\begin{array}{c}-0.007 \\
(2.227)^{\star *}\end{array}$ & $\begin{array}{c}-0.046 \\
(1.542)\end{array}$ & $\begin{array}{c}-0.075 \\
(2.551)^{\star *}\end{array}$ & \\
\hline$\triangle \ln E X^{+}$ & $\begin{array}{c}0.006 \\
(0.204)\end{array}$ & & & & \\
\hline$\triangle \ln E X-$ & $\begin{array}{c}0.035 \\
(0.876)\end{array}$ & & & & \\
\hline \multicolumn{6}{|c|}{ Panel B: Long-Run Coefficient Estimates } \\
\hline Constant & $\ln Y$ & $\ln r$ & $\ln E X^{+}$ & $\ln E X$ & DUM \\
\hline $\begin{array}{c}32.257 \\
(10.099)^{\star *}\end{array}$ & $\begin{array}{c}0.318 \\
(0.452)\end{array}$ & $\begin{array}{l}-0.203 \\
(0.612)\end{array}$ & $\begin{array}{c}0.552 \\
(1.875)^{*}\end{array}$ & $\begin{array}{c}0.446 \\
(0.546)\end{array}$ & $\begin{array}{c}0.483 \\
(0.877)\end{array}$ \\
\hline \multicolumn{6}{|c|}{ Panel C: Diagnostic Statistics } \\
\hline$F$ & $E C M_{\mathrm{t}-1}$ & $L M$ & RESET & $\operatorname{cUS}\left(\operatorname{CUS}^{2}\right)$ & Adj. $R^{2}$ \\
\hline $9.26^{* *}$ & $\begin{array}{c}-0.028 \\
(-6.952)^{\star *}\end{array}$ & 0.475 & 2.799 & Stable & 0.898 \\
\hline
\end{tabular}

Notes:

a. Numbers inside the parentheses are absolute values of the $t$-ratios.

b. The upper critical bound value of the F-statistic at the $10 \%$ significance level is 3.52. This comes from Pesaran et al. (2001), Table CI-Case III.

c. The critical value of the t-test for significance of $\mathrm{ECM}_{\mathrm{t}-1}$ is -3.67 the $10 \%$ significance level and -3.82 at the $5 \%$ level. They come from Banerjee et al. (1998, Table 1).

d. LM and RESET are the Lagrange multiplier test of serial correlation and Ramsey's test or functional form, respectively. These tests are based a $x^{2}$ distribution with one degree of freedom. The critical value at the $5 \%$ significance level is 3.84 .

e. ${ }^{* *}$ and ${ }^{*}$ denote significance at the $5 \%$ and $10 \%$ levels, respectively.

A few other diagnostic statistics are also reported in Panel C. To test for first-order autocorrelation, we rely upon the Lagrange Multiplier (LM) test which has a $\mathrm{X}^{2}$ distribution with one degree of freedom. Given its critical value of 3.84 , the LM statistic is insignificant, supporting autocorrelation-free residuals. We have also reported Ramsey's RESET statistic to test for misspecification. It also has a $X^{2}$ distribution with one degree of freedom. Clearly, the RESET statistic is also insignificance, implying that the optimum model is correctly specified. One issue of concern in estimating any money demand function is its stability. How stable are the short-run and long-run coefficient estimates? To answer this question, following the literature, we

exogenous variables. It comes from Banerjee et al. (1998, Table 1, page 276). apply the well-known CUSUM (indicated by CUS) and CUSUMSQ (indicated by $\mathrm{CUS}^{2}$ ) tests to the residuals of estimated optimum error-correction model. As we have indicated in Panel $\mathrm{C}$, all estimated coefficients are stable, again supporting the fact that the demand for money in Japan was not affected by Global Financial Crisis of 2008. Finally, the model enjoys a good fit reflected by the size of adjusted $R^{2}$.

The two main shortcomings of the results from the linear ARDL model (2) are lack of cointegration among the variables and insignificance of the nominal effective exchange rate in the short-run as well as in the longrun. Can decomposing the exchange rate changes to partial sums of negative and positive changes improve the results? To answer this question, we shift to Table 2 and full-information estimates of nonlinear ARDL model (5). From Panel A and short-run coefficient 
estimates, we gather that only income and interest rate carry significant coefficients in the short run. None of the partial sum variables not the dummy is significant. However, the story is somewhat different in the long run. Based on the results reported in Panel $B$, clearly,

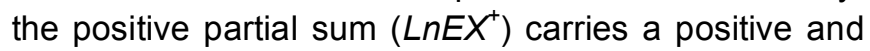
significant coefficient but the negative partial sum ( $L n E X)$ does not, supporting long-run asymmetric effects of exchange rate changes on the demand for money in Japan. The positive coefficient of 0.552 implies that, as yen appreciate, Japanese expect further appreciation of the yen. Thus, they hold less of foreign currency and more yen which supports expectation effect rather than the wealth effect of exchange rate on the demand for money. ${ }^{9}$ Like before, the income also carries its expected positive and significant coefficient in the long-run. However, the dummy variable is again insignificant.

Once again, in order for the long-run estimates to be valid, we need to establish cointegration. Clearly, cointegration is supported by both the $\mathrm{F}$ and $E C M_{\mathrm{t}-1}$ tests. $^{10}$ The fact that the variables were not cointegrated in the linear model but they are cointegrated in the nonlinear model supports nonlinear adjustment of the exchange rate and the nonlinear specification that is not still affected by Global Financial Crisis of 2008. Once again, the LM test supports autocorrelation free residuals and the RESET test supports correct specification of the nonlinear model. Again, short-run and long-run estimates are stable and the nonlinear model enjoys a good fit. Clearly, the results from nonlinear ARDL model are preferred to those from the linear model in that cointegration is supported by nonlinear model and not by linear model. Furthermore, nonlinear ARDL model helps us conclude that the exchange rate changes have asymmetric effect on the demand for money in Japan.

\section{SUMMARY AND CONCLUSION}

A few studies have estimated the demand for money in Japan by using Johansen cointegration technique and have interpreted cointegration as a sign

\footnotetext{
${ }^{9}$ Comparing 0.552 estimate for positive partial sum to 0.446 for the negative partial sum, one wonders if they are significantly different. Application of the Wald test resulted in an insignificant Wald statistic of 0.152 . The Wald test is distributed as $X^{1}(1)$.

${ }^{10}$ Note that due to dependency between the two partial sum variables, Shin et al. (2014, p. 291) recoomend treating them as one variable when it comes to test for cointegration. This implies using the same critical values that are used in the linear model. However, this is not the case for ECM test. Since there are four exogenous variables in the nonlinear ARDL model, the $10 \%$ critical value of the t-ratio from Banerjee et al. (1998, Table 1) is -3.67 . The comparable value at the $5 \%$ significance level is -3.82 .
}

of long-run relation between income, interest rate, and the exchange rate without testing for significance of each variable in the money demand function. Therefore, it is not easy to judge whether cointegration is due to strong relation between money and income or between money and all variables. Furthermore, an implicit assumption by all previous studies is that all variables have symmetric effects on the demand for money in Japan.

In this paper, we consider the demand for money in Japan one more time and try to determine if it was affected by the Global Financial Crisis of 2008. Our approach differs from previous research in a few ways. First, we use Pesaran et al.'s (2001) bounds testing or linear ARDL approach to model the money demand in Japan under which variables could be integrated of order zero or one or combination of the two, ruling out pre-unit root testing. When this method was applied to estimate the money demand in Japan, although income carried a long-run significant positive coefficient, we were unable to support cointegration among the variables. Next, we separated appreciation of the yen from depreciation by means of partial sum approach. We then applied nonlinear ARDL approach of Shin et al. (2014) to a specification that included income, interest rate, and two measures of yen appreciation and yen depreciation. Once this nonlinear ARDL model was estimated, we were able to support cointegration among the variables of nonlinear model. Long-run estimates revealed that cointegration is due to significant income effect and significant yen appreciation. The short-run and long-run results also supported the asymmetric effects of exchange rate changes on the demand for money in Japan. Moreover, the partial sum representing yen appreciation carried a significantly positive coefficient, implying that, as yen appreciates, Japanese expect further appreciation; hence they hold less foreign currency and more yen. All short run and long run estimates in both models were found to be stable and not affected by Global Financial Crisis of 2008.

\section{APPENDIX}

\section{Data Definition and Sources}

Quarterly data over the period 1973:Q1-2014:Q3 are used $d$ to conduct the empirical analysis. The data sources are as follows:

a. International Financial Statistics of the IMF (www.imfstatistics.org). 
b. Bank for International Settlements (www.bis.org).

\section{Variables:}

$M=$ Real money supply measured by M2. Nominal M2 is deflated by GDP deflator (source a).

$Y=\operatorname{Real} \operatorname{GDP}($ source $a)$.

$r=$ Interest rate defined as government bonds yield (source a).

$E X=$ Nominal effective exchange rate (the narrow index, source b). A decline reflects a depreciation of Japanese yen.

\section{REFERENCES}

Apergis, N., and S. Miller (2006) "Consumption Asymmetry and the Stock Market: Empirical Evidence" Economics Letters 93, 337-342.

http://dx.doi.org/10.1016/j.econlet.2006.06.002

Arango, Sebastian, and M. Ishaq Nadiri (1981), "Demand for Money in Open economies," Journal of Monetary Economics, Vol. 7, pp. 69-83.

http://dx.doi.org/10.1016/0304-3932(81)90052-0

Bahmani-Oskooee, M. (1996), "The Black Market Exchange Rate and Demand for Money in Iran" Journal of Macroeconomics, Vol. 18, pp. 171-176. http://dx.doi.org/10.1016/S0164-0704(96)80010-3

Bahmani-Oskooee, M. (2001), "How Stable is M2 Money Demand Function in Japan?", Japan and the World Economy, Vol. 13, pp. $455-461$. http://dx.doi.org/10.1016/S0922-1425(01)00064-0

Bahmani-Oskooee, M. and M. Malixi (1991), "Exchange Rate Sensitivity of the Demand for Money in LDCs." Applied Economics, Vol. 23, pp. 1377-1384 http://dx.doi.org/10.1080/00036849100000060

Bahmani-Oskooee, M. and G. Shabsigh (1996), "The Demand for Money in Japan: Evidence from Cointegration Analysis", Japan and the World Economy, Vol. 8, pp. 1-10. http://dx.doi.org/10.1016/0922-1425(95)00002-X

Bahmani-Oskooee, M. and A. Tanku, (2008), "The Black Market Exchange Rate vs. the Official Rate in Testing PPP: Which Rate Fosters the Adjustment Process", Economics Letters, Vol. 99, pp. 40-43. http://dx.doi.org/10.1016/j.econlet.2007.05.024

Bahmani-Oskooee, M. and S. Chomsisengphet (2002), "Stability of M2 Money Demand Function in Industrial Countries", Applied Economics, Vol. 34, pp. 2075-2083. http://dx.doi.org/10.1080/00036840210128744

Bahmani-Oskooee, M. and S. Bahmani (2015), "Nonlinear ARDL Approach and the Demand for Money in Iran", Economics Bulletin, Vol. 35, pp. 381-391.

Bahmani-Oskooee, M., Y. Wang, and D Xi, (2012), "Economic Uncertainty, Monetary Uncertainty and the Demand for Money in China", The Chinese Economy, Vol. 45, pp. 26-37. http://dx.doi.org/10.2753/CES1097-1475450602

Banerjee, A., J. Dolado, and R. Mestre (1998), "Error-Correction Mechanism Tests in a Single Equation Framework," Journal of Time Series Analysis, Vol. 19, pp. 267-85. http://dx.doi.org/10.1111/1467-9892.00091

Chen, Shyh-Wei and Tzu-Chun Chen, (2012) "Untangling the NonLinear Causal Nexus between Exchange Rates and Stock Prices: New Evidence from the OECD Countries", Journl of
Economic Studies, Vol. 39, pp. 231-25.

http://dx.doi.org/10.1108/01443581211222671

Cheung, Yin-Wong and K. S. Lai, (1993), "Finite-Sample Sizes of Johansen's Likelihood Ratio Tests for Cointegration", Oxford Bulletin of Economics and Statistics, 55 (3), 313-328. http://dx.doi.org/10.1111/j.1468-0084.1993.mp55003003.x

Civcir, I. (2003), "Money Demand, Financial Liberalization and Currency Substitution in Turkey", Journal of Economic Studies, Vol. 30, pp. 514-534. http://dx.doi.org/10.1108/01443580310492817

De Vita, G. and K. S. Kyaw, (2008), "Determinants of Capital Flows to Developing Countries: A Structural VAR Analysis", Journal of Economic Studies, Vol. 35, pp. 304-322. http://dx.doi.org/10.1108/01443580810895608

Delatte, Anne-Laure and Antonio Lopez-Villavicencio (2012), "Asymmetry Exchange Rate Pass-Through: Evidence from Major Countries", Journal of Macroeconomics, Vol. 34, pp. 833-844. http://dx.doi.org/10.1016/j.jmacro.2012.03.003

Domowitz, I. and I. Elbadawi (1987), "An Error-Correction Approach to Money Demand: The Case of Sudan", Journal of Development Economics, Vol. 26, pp. 257-275. http://dx.doi.org/10.1016/0304-3878(87)90029-0

Engle, R. F., and C.W.J. Granger (1987), "Co-Integration and Error Correction: Representation, Estimation, and Testing", Econometrica, Vol. 55, pp. 251-276. http://dx.doi.org/10.2307/1913236

Fair, Ray C. (1987), "International Evidence on the Demand for Money", The Review of Economics and Statistics, Vol. 69, pp. $473-480$. http://dx.doi.org/10.2307/1925535

Hajilee, Massomeh, and Omar M. Al-Nasser, (2014), "Exchange Rate Volatility and Stock Market Development in Emerging Economies", Journal of Post Keynesian Economics, Vol. 37 , pp. $163-180$. http://dx.doi.org/10.2753/PKE0160-3477370110

Halicioglu, F., (2007), "The J-Curve Dynamics of Turkish Bilateral Trade: A Cointegration Approach", Journal of Economic Studies, Vol. 34, pp. 103-119. http://dx.doi.org/10.1108/01443580710745362

Harb, N. (2004), "Money Demand Function: A Heterogeneous Panel Application", Applied Economics Letters, Vol. 11, pp. 551555. http://dx.doi.org/10.1080/1350485042000225739

Hoffman, Dennis L., Robert H. Rasche, and Margie A. Tieslau (1995), "The Stability of Long-Run Money Demand in Five Industrial Countries", Journal of Monetary Economics, Vol. 35, pp. 317-339. http://dx.doi.org/10.1016/0304-3932(95)01189-U

Johansen, S. (1988), "Statistical Analysis of Cointegration Vectors", Journal of Economic Dynamics and Control, Vol. 12, pp. 231254. http://dx.doi.org/10.1016/0165-1889(88)90041-3

Karfakis, C.I. (1991), "Monetary Policy and the Velocity of Money in Greece: A Cointegration Approach", Applied Financial Economics, Vol. 1, pp. 123-127. http://dx.doi.org/10.1080/758518037

Marquez, J. (1987), "Money Demand in Open Economies: A Currency Substitution Model for Venezuela", Journal of International Money and Finance, Vol. 6, pp. 167-178. http://dx.doi.org/10.1016/0261-5606(87)90031-3

McNown, R. and M.S. Wallace (1992) "Cointegration Tests of a Long-Run Relationship between Money Demand and the Effective Exchange Rate" Journal of International Money and Finance 11, 107-114. http://dx.doi.org/10.1016/0261-5606(92)90024-R

Miyao, R., (1996) "Does a Cointegrating M2 Demand Relation Really Exist in Japan?, Journal of the Japanese and International Economies, Vol. 10, pp. 169-180. 
http://dx.doi.org/10.1006/jije.1996.0009

Mohammadi, H., M. Cak, and D. Cak, (2008), "Wagner's Hypothesis: New Evidence from Turkey using the Bounds Testing Approach", Journal of Economic Studies, Vol. 35, pp. 94-106. http://dx.doi.org/10.1108/01443580810844442

Mundell, A. Robert (1963), "Capital Mobility and Stabilization Policy under Fixed and Flexible Exchange Rates," Canadian Journal of Economics and Political Science, Vol. 29, pp. 475485. http://dx.doi.org/10.2307/139336

Narayan, P.K., S. Narayan, B.C. Prasad, and A. Prasad, (2007), "Export-led Growth Hypothesis: Evidence from Papua New Guinea and Fiji", Journal of Economic Studies, Vol. 34, pp. 341-351. http://dx.doi.org/10.1108/01443580710826380

Payne, J. E., (2008), "Inflation and Inflation Uncertainty: Evidence from the Caribbean Region", Journal of Economic Studies, Vol. 35, pp. 501-511. http://dx.doi.org/10.1108/01443580810916523

Pesaran, M. H.' Y. Shin, and R. J. Smith, (2001), "Bounds Testing Approaches to the Analysis of Level Relationships," Journal of Applied Econometrics, Vol.16, pp. 289-326. http://dx.doi.org/10.1002/jae.616

Shin, Y, B. C. Yu, and M. Greenwood-Nimmo (2014) "Modelling Asymmetric Cointegration and Dynamic Multipliers in a Nonlinear ARDL Framework" Festschrift in Honor of Peter Schmidt: Econometric Methods and Applications, eds. by R. Sickels and W. Horrace: Springer, 281-314. http://dx.doi.org/10.1007/978-1-4899-8008-3 9

Tang, T.C., (2007), "Money Demand Function for Southeast Asian Countries: An Empirical View from Expenditure Components", Journal of Economic Studies, Vol. 34, pp. 476496. http://dx.doi.org/10.1108/01443580710830952

Verheyen, F. (2013), "Interest Rate Pass-Through in the EMU-New Evidence Using Nonlinear ARDL Framework", Economics Bulletin, Vol. 33, No 1, pp. 729-739.

Wong, K. N. and T. C. Tang, (2008) "The Effects of Exchange Rate Variablity on Malaysia's Disaggregated Electrical Exports", Journal of Economic Studies, Vol. 35, pp. 154-169. http://dx.doi.org/10.1108/01443580810870146

Received on 12-05-2015 Accepted on 01-06-2016

Published on 17-08-2016

DOI: http://dx.doi.org/10.6000/1929-7092.2016.05.23

(C) 2016 Bahmani-Oskooee and Baek; Licensee Lifescience Global.

This is an open access article licensed under the terms of the Creative Commons Attribution Non-Commercial License (http://creativecommons.org/licenses/by-nc/3.0/) which permits unrestricted, non-commercial use, distribution and reproduction in any medium, provided the work is properly cited. 